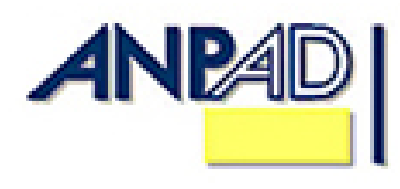

Available online at http://www.anpad.org.br/bar

BAR, Rio de Janeiro, v. 10, n. 4, art. 3, pp. 415-438, Oct./Dec. 2013

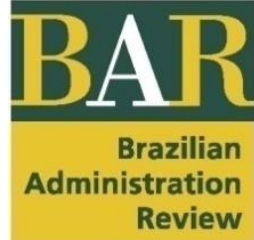

$(\mathrm{cos}) \mathrm{EY}-\mathrm{NC}$

\title{
The Role of Home Country Political Resources for Brazilian Multinational Companies
}

\author{
Karina Regina Vieira Bazuchi \\ E-mail address: kari_bazuchi@yahoo.com.br \\ Fundação Getúlio Vargas - FGV-EAESP
}

Av. 9 de Julho, 2029, Bela Vista, 01313-902, São Paulo, SP, Brazil.

Suelen Alice da Silva Zacharias

E-mail address: suelen.zacharias@ gmail.com

Fundação Getúlio Vargas - FGV-EAESP

Av. 9 de Julho, 2029, Bela Vista, 01313-902, São Paulo, SP, Brazil

Laurent Wiliam Broering

E-mail address: laurent.broering@ gmail.com

Fundação Getúlio Vargas - FGV-EAESP

Av. 9 de Julho, 2029, Bela Vista, 01313-902, São Paulo, SP, Brazil

Maria Fernanda Arreola

E-mail address: fernanda.arreola@gmail.com

Fundação Getúlio Vargas - FGV-EAESP

Av. 9 de Julho, 2029, Bela Vista, 01313-902, São Paulo, SP, Brazil

Rodrigo Bandeira-de-Mello

E-mail address: rodrigo.bandeira.demello@fgv.br

Fundação Getúlio Vargas - FGV-EAESP

Av. 9 de Julho, 2029, Bela Vista, 01313-902, São Paulo, SP, Brazil

Received 31 October 2012; received in revised form 25 June 2013 (this paper has been with the authors for two revisions); accepted 24 July 2013; published online $1^{\text {st }}$ October 2013. 


\begin{abstract}
This paper aims to analyze the interactions between home country governments and Developing Country Multinational Companies (DMNCs). Drawing on evidence from the Brazilian political environment and Brazilian multinationals we investigate the mechanisms governments use to influence the internationalization process of domestic companies and firms' political strategic responses to shape the political institutional environment in which they operate. We argue that foreign direct investment (FDI) outflows from developing economies need to be explored given specific country level contextual factors, such as high levels of government involvement. Our main findings support this idea and indicate that home country governments use a series of formal and informal mechanisms in order to drive the international expansion of DMNCs in both the entry and consolidation phases. Moreover, DMNCs political behavior in the home country political environment accounts for an important part of their strategy to develop political resources and obtain above average returns from governmental benefits.
\end{abstract}

Key words: competitive advantage; interactions between companies and governments; developing country multinational companies. 


\section{Introduction}

This paper aims to analyze the interactions between home country governments and Developing Country Multinational Companies (DMNCs). Building on evidence from the Brazilian political environment and Brazilian multinationals, we uncover the mechanisms of government influence in the internationalization process of domestic companies and firms' political strategic responses to shape public policy process. The research seeks to contribute to a growing body of studies oriented towards understanding DMNCs' international insertion. DMNCs have been shown to have different strategic choices that can be explained by their context, country of origin, industry and size (Ramamurti, 2012). We intent to explore how the political component embedded in international business activity has an influence in such choices and impacts DMNC entrance in new markets, a subject that has been only marginally discussed by International Business (IB).

Recent interest in understanding the internationalization of DMNCs was motivated by a systemic change in global FDI flows. In 2010, developing and transition economies share of global FDI outflows increased to 28\%, up from 15\% in 2007 (United Nations Conference on Trade and Development [UNCTAD], 2011), while during the 1980's DMNCs accounted only for shares between 3 to $9.6 \%$ of world outward FDI. Furthermore, DMNCs have special particularities that influence their international strategies. They are generally state-owned or recently privatized companies organized in business groups, which together accounted for a third of the emerging world's foreign direct investment in the period of 2003-10, according to data from UNCTAD (2012); they have adopted distinctive approaches to internationalization (Goldstein, Bonaglia, \& Mathews, 2006); and developed a symbiotic relationship with governments (Schneider \& Soskice, 2009). Thus, FDI outflows from developing countries should be understood considering contextual factors such as high levels of government involvement, industry structures, ownership patterns, and business law enforcement (Wright, Filatotchev, Hoskisson, \& Peng, 2005).

Despite the fact that the political environment is pointed out as a constrainer or supporter of DMNCs strategies, only anecdotal information exists about how, and through which mechanisms, the interaction between DMNCs and governments occurs. This paper fills this gap by providing an indepth analysis about the mechanisms of interaction between multinationals and home country governments based on evidence from Brazil, a democracy with a history of both developmental and liberal governments. First, it investigates the influence of the Brazilian government as a driver of the international expansion of domestic firms in both entry and consolidation phases in the foreign market. Second, our research focuses on the political component of multinational corporations' (MNCs) strategies, incorporating firms as actors not only constrained by the political institutional environment, but also able to influence policy outcomes. Most IB studies take institutions for granted or only as constraint factors, focusing on how MNCs can mitigate political risk when host countries impose fiscal and regulatory reforms or restrictions to finance mechanisms (Henisz, 2000; Holburn \& Zelner, 2010). In fact, in developing countries, political activity is an alternative corporate strategy to overcome lack of market institutional support. While Corporate Political Activity (CPA) and IB streams together provide a broad perspective of international business-government interactions, there is a great need for a better integration of the two literatures (Blumentritt \& Night, 2002). Studies about MNE-government relations tend to stand by themselves, without attempting to integrate explicitly into MNC theory (Boddewyn, 1988).

To examine the mechanisms of DMNCs-government interaction we first present a brief review about the role assigned to home country governments on IB research and the literature about corporate political strategy. We also point to the relevance of industrial and foreign trade policies in shaping the importance that political connections have gained in the case of DMNCs. We then describe our research methodology, our study sample and our main findings, proposing constructs to classify DMNC-home country government mechanisms of interaction. Finally, we present our conclusion and discuss evidence that suggest an association between DMNCs political behavior and above average benefits from home country government. 


\section{DMNCs and the Role of the Home Country Government}

Governments meaningfully affect firms' performance, operations and governance, and the market environment in which they compete (Marcus, Kaufman, \& Beam, 1987) because of the way they distribute the burdens and benefits among firms. As Boddewyn (1988) stressed, non-market actors, such as governments, support market transactions through power and other noneconomic sanctions and, therefore, need to be accounted for in the IB perspective. Governments can subsidize financial resources, create and enforce jurisdiction on hostile acquisitions, release public tenders and own effective controlling interest in corporate entities, as in state-owned companies and sovereign funds, facilitate MNCs' market access, dialogue with foreign governments and international organizations, and even impose barriers to the transfer of factors of production and ownership control. They are aware that through MNCs they develop the ability to connect the local economy to the outside world (Luo, 2004) and can implement public policies, such as industrial and foreign policy.

In many emerging economies, globalization and an exogenous increase in the portion of the economy that was exposed to international competition have induced changes in economic preferences and market and political power reorganization. Although exogenous forces have spread market reforms and an increase in internationalization levels in many countries, policy outcomes can only be explained at a country specific level. This is because differences in actor's preferences are not directly reflected as changes in domestic policies; they are mediated by institutions (Garret \& Lange, 1995).

Since it is our interest in this paper to understand domestic policies that support firm internationalization, it is necessary to look at both the political conflict shaped by the preferences of different actors, weighted by their market power and their propensity for collective action and the role of extant political and macroeconomic institutions of a country.

Garret and Lange (1995) support that governments' responsiveness to changes in domestic preferences will vary significantly according to institutional arrangements, considering regime type (how easy is to challenge the policies of the incumbent government), the level of government dependence on the core group that support the status quo, the number of veto points in the political system (inversely correlated) and the level to which authority over policy rests in the hands of independent bureaucratic agencies.

One of the most interesting features that characterized the DMNC internationalization process is the involvement of developing country governments that support international activities of firms from their country (Sargent \& Ghaddar, 2001). This involvement responds to historical paths that are not shared by their developed country counterparts. As presented by Gammeltoft, Pradhan, and Goldstein (2010) in the special issue of the Journal of International Management, in emerging economies.

Central and local governments play a larger and more active role in the economy, and firms tend to be more attuned to government priorities and preferences. Government support also provides emerging economy firms with privileged access to certain inputs, preferential financing, subsidies and other support (p. 1).

For instance, researchers divide the expansion of emerging multinationals into three different periods. In the first wave of internationalization, governments from emerging countries relied on import-substitution policies (Lall, 1983) and consequently stimulated production directed at the domestic market. The second wave, dominated by Asian firms, was defined by export-oriented industrialization, which targeted the creation of large players that could seek previously unavailable assets and markets, allowing local firms to build their international competitiveness (Rasiah, Gammeltoft, \& Jiang, 2010). This second wave led to the growth of many of the central actors of the third wave of Internationalization, (Rasiah et al., 2010), which brought more market power (especially for firms trading in natural resources). 
Industrial and trade policies were key drivers for the increase in OFDI coming from these nations (Rasiah et al., 2010). Governments had a special interest in capturing the benefits that can result from OFDI and in regulating the way in which these policies affected their internal positioning. This resulted in a number of protectionist policies in Asia and Latin America, that for the latter represented the surge of organized sectors of production safeguarded by tariff walls (Etzkowitz \& Brisolla, 1999).

In our view, the case of Brazil is representative of many emerging economies as it shares many of the steps that came into defining a policy agenda. Specifically Brazil places a lot of importance in its industrial policies as part of its effort to become a player in the international arena $(1 \& 5)$. The government has had an important involvement in the creation of policies that support sectors deemed strategic, such as the automotive and petrochemical industries (Shapiro, 1994) and currently holds an ownership position in many of the most internationalized DMNCs in the country (6).

In reality, policy changes come as part of an effort to adapt emerging economies' procedures and mechanisms of interaction with companies against those from developed countries, since DMNCs have unique characteristics and behaviors (Sargent \& Ghaddar, 2001). DMNCs develop different competences in comparison to traditional MNCs, such as cost advantages and political competences, due to contextual characteristics like their history in unstable political and economic environments and less capital-intensive markets. Emerging economies suffered from a remarkable failure to build up firm-specific advantages to drive FDI and make it profitable (Murtha \& Lenway, 1994). Local governments tend to engage and even coordinate regulatory and financing activities in order to compensate for the late mover position of DMNCs (Rasiah et al., 2010).

Current literature covers only a few issues regarding home country government influence on DMNC internationalization. For example, DMNCs' experience in turbulent political environments can have a positive effect on the development of political capabilities; i.e., organizational capabilities for assessing policy risk and managing the policy-making process, which can be transferred to operations in similar institutional environments and guarantee DMNCs a competitive advantage in comparison to MNCs from developed countries (Holburn \& Zelner, 2010). The literature also suggests that FDI can be an escape response to home country factors such as high tax rates (Caves, 1996) and lack of institutional alignment with firm's needs (Witt \& Lewin, 2007).

\section{Multinational political activity}

The way in which governments and firms interact is one of the key components of MNC internationalization theories (Dunning, 1988). Since companies depend on governments to realize their profits, it is important that they be politically underwritten in a way that gives them a high degree of representation (Schneider \& Soskice, 2009). Through political activity, companies seek to protect themselves from government opportunism (Henisz \& Williamson, 1999), and to gain legitimacy and political rents resulting from government action as a regulator and factor of production.

The growing entanglement of the public and private sectors has encouraged many corporations to reassess their existing methods for interacting with the government (Marcus et al., 1987). Hillman and Hitt (1999) developed a framework to account for businesses' political strategic formulation. They argue that firms can employ information, financial incentives and constituency building strategies and this decision depends on the issue, its frequency and also on the political environment of the country in which the firm operates (Blumentritt \& Night, 2002). There are different mechanisms available, including lobbying, public and government relations, alliances with other firms and bribery (Hillman \& Hitt, 1999), which can be used individually or combined in order to exploit political rents and to raise the transaction costs for competing firms.

One of the key decisions companies must make regarding their non-market strategies is related to collective versus individual action. Although individual undertaking may lead to superior returns in comparison to industry competitors, the initial decision of establishing a public affairs office and developing public affairs capability is costly and difficult to revoke (Blumentritt, 2003). According to 
transaction cost theory, the coordination in the nonmarket environment will vary according to the frequency of dependencies and the types of human assets (specific/ nonspecific) (Ring \& Van de Ven, 1992). When firm and industry interests are congruent, investments in nonspecific human assets at the trade association level are likely to occur. However, interests within industries are often seriously divided and therefore groups cannot engage in frequent and effective collective action, forcing a firm to invest in specific human assets in order to develop political expertise or acquire it from a consulting firm. It is quite plausible that a single firm facing multiple issues of relevant government dependence will pursue each of these strategies simultaneously (Marcus et al., 1987).

\section{Research Methodology}

We conducted a qualitative analysis in order to uncover the mechanisms of interaction between governments and DMNCs and their effect on a firm's international insertion. As a process data analysis, it provides means to conceptualize events and detect patterns among them (Langley, 1999), which can be later categorized and inspire propositions for future research. We chose Brazil, given that most of the country's MNCs are leading companies in their sector (Fleury \& Fleury, 2009), such as the animal protein industry. The case serves to describe the internationalization of DMNCs as it captures the behavior of companies that have followed similar internationalization paths to those signaled in the literature as traditional of emerging multinationals, such as being late movers and focusing on acquisition (Fleury \& Fleury, 2011).

Our research was built upon primary information gathered around two Brazilian MNCs, one a public investment agency and one a business association. We also collected secondary data, such as financial and industrial reports, economic indicators and case studies published from 1994 to 2011. Due to the sensitivity of political issues, the secondary data was an important source for understanding the phenomena studied and for making triangulations.

The interviews were conducted from July to October 2011 and addressed not only the companies' own experiences but also changes in industry and competition patterns. We selected two Brazilian MNCs from the animal protein sector listed in the Valor Multinational/Sobeet ranking for most internationalized companies in Brazil. This ranking, published by one of Brazil's most respected business magazines, measures companies' internationalization indices through the number of jobs, assets and revenue aboard. In 2010, firm 1 had net revenue around US\$27.5 billion and a large public shareholder participation owned by a public bank. Firm 2 had net revenue of approximately US\$12.5 billion and is characterized by a good degree of maturity in operational performance, as well as stock ownership by state-owned pension funds.

We interviewed directors, managers and analysts of the areas related to internationalization, institutional and investor relations. We used secondary information to formulate questions directly related to issues of internationalization, investments and public policies. In each interview, at least two researchers were present to take field notes. We recorded the interviews when allowed. Afterwards, we complemented our secondary data with information mentioned by our informants, such as foreign investments, political connections and financial loans.

In order to allow a holistic view of the process we interviewed representatives from an industry federation and an investment promotion agency. Organization 3 is a private industry federation whose mission is to represent industrial interests in society, including in public spheres, by giving assistance on issues like advocacy, market intelligence, customs clearance and trade promotion. Organization 4 is a state investment promotion agency that aims to facilitate dialogue between business and foreign governments to attract foreign direct investment. We complemented interviews with data about public development banks loans, public agency mandates and industrial policy programs. 
The data was collectively analyzed in group sessions in order to increase internal validity. These analysis sessions took place during the period from May 18 until November 24, 2011. The examination was conducted using simple categorical qualitative analysis through an inductive method. The construction of the final conceptual framework was devised as a functional model with data and extant literature integration. In order to further validate our model, we conducted a new data collection, essentially from secondary sources, in order to strengthen, refute and refine the framework developed and avoid mis-fitting data.

As not all relevant information collected from interviewees and secondary sources could be included in our discussion, we have provided an additional annex (Annex A) at the end of this paper, in order to add more evidence on the mechanisms of political influence identified in the research.

\section{Discussion and Findings}

This section is divided in two subsections. The first section considers the influence of the Brazilian government in the internationalization process of Brazilian MNCs and describes ways of government's influence considering the institutional channels of dialogue between firms and governments and their level of formality. The second section identifies political strategies used by Brazilian MNCs in their home country environment.

\section{Home country government's influence on Brazilian MNCs}

Research connecting business and politics recognizes the role of the government as a regulator and factor of production (Boddewyn \& Brewer 1994). They have the ability to alter firms' size, market and cost structure and affect the demand for products and services (Hillman \& Hitt, 1999). In order to do this, governments use many instruments, including but not limited to antitrust legislations, taxation, credit lines and direct purchase.

The Brazilian government's agenda shows a growing interest in national MNCs' activities. Public policies directed to enhance Brazilian companies' competitiveness and international expansion have been developed since the 1990's. Although government's role has changed in comparison to previous periods that were characterized by import-substitution industrialization policies, the government has kept its interventionist bent and maintains for itself the role of selecting and promoting strategic sectors, as indicated in the following excerpt from The Economist, (2010),

In some cases the state actively promotes industrial concentration, to help firms gain the scale to compete abroad. In the 1990s a privatizing government got around the scarcity of capital and know-how by coaxing state-owned pension funds to co-operate with private companies, and pushed public banks into giving them subsidized loans. Today Brazil's firms are stronger and its capital markets deeper. But the government continues to intervene.

Government's role is more evident in initial phases of the internationalization process, specifically during the entry phase in new markets. Even before the international expansion of Brazilian MNCs, the Brazilian government predisposed industry concentration in strategic sectors in order to build national champions able to compete with incumbent MNCs in the international market. With the rapid international expansion of Brazilian MNCs, government involvement during both the entry and expansion phases has increased.

As noticed in our interviews, "governments are not unique and cohesive organizations; they have a series of internal disputes" (Organization 3, field note). This means that public policies can have mixed effects for Brazilian MNCs. But since internationalization promotion has reached consensus in the Brazilian public agenda, the government has recently created public and capital agencies that act as direct channels of interaction with MNCs and have the role to: (a) assign political 
meaning to and consolidate unique visions for MNC demands before any of their negotiations with other governmental actors, where the dispute for public policies and public funds is more intense; and (b) make sure MNCs interests are represented in the three branches of government.

Data analysis indicated that governments use a series of formal and informal reinforcement mechanisms to interact with MNCs, which were categorized as shown in Table 1. It also presents the constructs that we studied as a way of showing the cognitive process used to interpret and explain our main findings. Furthermore, it helps to establish linkages between empirical work and conceptual development.

Table 1

Evidence of Home Country Government Influence on National MNCs

\begin{tabular}{ll}
\hline \multicolumn{1}{c}{ Constructs } & \multicolumn{1}{c}{ Evidences } \\
$\begin{array}{l}\text { Supply of subsidized resources to } \\
\text { internationalization }\end{array}$ & $\begin{array}{l}\text { MNCs' material facts related to BNDE's (Brazilian } \\
\text { Development Bank) loans. }\end{array}$ \\
BNDES' loans to internationalization projects of Brazilian \\
companies (BNDES website).
\end{tabular}

Note. Source: elaborated by authors.

\section{Supply of subsidized resources for internationalization}

Public institutions are key financial resources for private companies in Brazil. This is likely explained by the lack of private bank involvement in long-term corporate bonds as well as by the developing state of the Brazilian stock market.

Through $O$ Banco Nacional de Desenvolvimento (BNDES) and its commercial branch, BNDESPAR, the government increases the mechanisms and modalities of financing internationalization support, following the guidelines of industrial policy plans, such as the Brazilian Productive Development Policy (PDP), which has granted priority to internationalization projects of selected sectors like animal protein processing, as presented in Table 2. Interviewees from Firm 1 pointed out that the proceedings to obtain BNDES's loans started when the company outlined an aggressive international expansion plan, stressing that it would not be possible to obtain such resources on the market with similar conditions. Two Brazilian MNCs operating in the animal protein industry have occupied the top positions as BNDES's loan receivers. 
Table 2

\section{BNDES's Loans to Largest Animal Protein Processing Brazilian MNCs}

\begin{tabular}{|c|c|c|c|}
\hline Year & Client & Project Description & Total (in BRL) \\
\hline \multirow[t]{2}{*}{2010} & MARFRIG & Support to subscription of convertible debentures. & $2,500,000,000$ \\
\hline & & Financing for working capital & $200,000,000$ \\
\hline \multirow[t]{3}{*}{2009} & JBS S/A & Internationalization of local companies & $3,479,600,000$ \\
\hline & $\begin{array}{l}\text { BRASIL } \\
\text { FOODS }\end{array}$ & $\begin{array}{l}\text { Purchase of common stock, emission of BRF Brasil Foods S.A., } \\
\text { previously Perdigão S.A., total amount of BRL } \$ 1 \text { billion, in the } \\
\text { scope of company's initial public offering. }\end{array}$ & $750,000,000$ \\
\hline & Bertin & Financing for working capital, special credit program scope & $200,000,000$ \\
\hline \multirow[t]{5}{*}{2008} & Bertin & $\begin{array}{l}\text { Consolidation of the "Bertin's internationalization program" } \\
\text { through acquisition of new companies, as well as modernization } \\
\text { and amplification of existing factories and implementation of } \\
\text { new industrial unities. }\end{array}$ & 2.499.929.732 \\
\hline & JBS S/A & $\begin{array}{l}\text { Investments related to the company internationalization } \\
\text { strategy. }\end{array}$ & $1,109,267,813$ \\
\hline & MARFRIG & $\begin{array}{l}\text { Support to the company's investment program through } \\
\text { BNDESPAR private stock. }\end{array}$ & $700,000,000$ \\
\hline & SADIA & $\begin{array}{l}\text { Addition of resources for implementation of its domestic } \\
\text { Project, involving the construction of new poultry and swine } \\
\text { slaughterhouses, a new feed factory and swine manufacturer } \\
\text { unity, and the construction of a housing development for } \\
\text { company employees. }\end{array}$ & $329,844,777$ \\
\hline & PERDIGÃO & $\begin{array}{l}\text { Amplification and modernization of industrial unity, in order to } \\
\text { increase slaughter capacity from } 50 \text { to } 280 \text { thousand poultry per } \\
\text { Day. }\end{array}$ & $156,593,796$ \\
\hline
\end{tabular}

Note. Source: elaborated by authors based on data from Banco Nacional de Desenvolvimento. (n. d.). Consulta às operações do BNDES. Retrieved from http://www.bndes.gov.br/SiteBNDES/bndes/bndes_pt/Institucional/BNDES_Transparente/Consulta_as_operacoes_do_BND ES/

BNDES has a specific credit line to finance internationalization of companies with national control that aims to build new subsidiaries abroad, acquire or expand installed unities and raise its share participation. Since 2004, BNDES' operations that aimed at internationalization have increased significantly, as showed by Table 3 .

Table 3

BNDES - OPERATIONS AIMED at Internationalization (in millions of BRL)

\begin{tabular}{cccc}
\hline Period & Qualifications & Approvals & Spending \\
\hline 2004 & 3.70 & - & - \\
2005 & 209.00 & 197.20 & 192.20 \\
2006 & $1,065.00$ & 955.00 & 970.80 \\
2007 & $5,091.50$ & $1,630.10$ & $1,223.20$ \\
\hline
\end{tabular}


Table 3 (continued)

\begin{tabular}{cccc}
\hline Period & Qualifications & Approvals & Spending \\
\hline 2008 & $1,842.80$ & $4,309.20$ & $4,237.30$ \\
2009 & $4,484.80$ & $3,588.90$ & $2,265.30$ \\
2010 & $2,510.00$ & $2,589.40$ & $3,849.20$ \\
\hline Total & $15,206.70$ & 13.83 & $12,738.00$ \\
\hline
\end{tabular}

Note. Source: AINT, DEINT, extracted from Valor Multinacionais Brasileiras. (2011, setembro). Valor Econômico, Ano 4 (4). Retrieved from http://www.revistavalor.com.br/home. $a s p x$ ?pub=3\&edicao $=4$

\section{Government's shareholder participation}

During the 1990s a series of privatizations and other liberal reforms undertaken in Brazil changed the ownership structure of domestic companies. Nonetheless, there are still important stateowned Brazilian MNCs, like the giant oil manufacturer, Petrobras, and the biggest power utility in Latin America, Eletrobras. Another interesting example is Embraer, global leader of regional jets privatized in 1994, but still under government direct influence since the latter has kept a golden share right. Governments can also be shareholders of corporate entities, owning stakes of private and independent corporate entities. BNDESPAR and state-owned pension funds are the main Brazilian governmental branches of shareholder participation. In the end of 2011, BNDES had direct shareholder participation in 154 companies, concentrated in the oil and gas, mining, electricity, foodstuff, pulp and paper and telecommunication sectors (BNDES, 2011). Government decisions acts as a selective tool, choosing which sectors and firms receive government investment instead of relying on market mechanisms where companies can count on governments as a lender of last resort.

Although government agencies are contingent to legal requirements and industrial policy guidelines, in Brazil there is still space to pick the winners. For example, in terms of shareholding, BNDES' best practices indicate that the bank has to respect a 30\% limit. An exception is allowed for infant and technology-based companies, where shareholder participation can achieve a $40 \%$ share. However, in JBS's case, one of the largest Brazilian MNCs in the animal protein sector, BNDES' stake rose from $17 \%$ to more than $30 \%$ in 2011 . The additional financial support was granted in order to reduce uncertainties related to JBS Initial Public Offering (IPO) on the USA stock market, which was not realized. BNDES policy exemplifies a government's influence on both entry and expansion phases of internationalization for Brazilian MNCs.

\section{Favorable regulation and legislation}

Governments have the opportunity to create, enforce and interpret the rules and norms that govern firms' interactions with employees, suppliers, competitors and within the financial, vocational training and social security systems, among others. While the Legislative body proposes broad directives through laws, the execute branch enforces them through specific regulations and the judiciary interprets them and provides the mechanisms for dispute resolution. This means that the three branches of government may influence MNCs' coordination.

Studies in the matter have characterized the Brazilian government as a non-facilitator, erratic in the formulation of rules, weak and hostile for private companies (Pearce, 2001). Some of our interviewees corroborated this idea, indicating that there are major difficulties related to government influence on business in Brazil. Most complaints pointed out that bureaucracy, delay in conflict resolution and the complexity, contestability and lack of clarity of the tributary system represented serious burdens to local companies. These additional burdens made companies delay their internationalization process. However, since the 1990s the Brazilian government has been engaged in compensating internal additional costs to internationalization. It is interesting to note that the learning experience in the home country has influenced the types of competencies gained by Brazilian MNCs. 
For example, they developed operational excellence and political capabilities to survive in times of high inflation and political turbulence. Brazilian MNCs are now characterized as flexible and able to rapidly adapt to external changes.

Brazilian MNCs have a positive perception about governmental technical entities, responsible for issues like sanitary and external trade regulation. Government-MNC relations on such issues are mediated through established dialogue channels, making it easier for the firm to register new products or get permits for new plant factories, for example. In the case of animal protein processing firms, there is an open dialogue with the Brazilian Ministry of Agriculture. This was considered really important for the researched MNE's export activities since: "in order to supply international markets, companies have to comply with international sanitary requirements. Foreign missions can come to Brazil, or they can delegate the licensing process to Brazilian government" (Firm 2, field note). The Brazilian government has, according to them, the expertise to deal with such requirements.

In addition, competition policy regulation in Brazil exemplifies how governments can reinforce their roles in picking the winners in the domestic context and build them to compete in international markets. The Economist (2010) provides evidence that support this idea:

Antitrust policy has long been weak in Brazil. In the 1990s the country started opening its economy and privatizing firms in order to increase competition. But a study in 2007 by Edmund Amann of the University of Manchester and Werner Baer of the University of Illinois found that 15 years later, the market share of the top four companies in most sectors had become even greater.

Yet, recent changes in Brazil's Council of Economic Defense (CADE, the national competitive authority with preventive, repressive and educational duties) may change this scenario. All major players in the Brazilian animal protein sector have been or are under investigation by the agency. It is worth noting that $\mathrm{CADE}$ can be characterized as an independent agency that can operate on politically sensitive cases far from government pressure (Drago \& Nogueira, 2013).

We can explain the prior experiences by utilizing the framework for the Brazilian Industrial Policy proposed by Hay (1999). In his work, Hay recognizes two types of policy that the government can create in order to deal with potential market failures: general industrial policies and sectorial or vertical policies. General industrial policies are related to creating appropriate models of competition while vertical policies are set to provide specific sectors with time to adjust to abrupt changes in market conditions that could affect issues of national interest, like technological development and employment (Hay, 1999). As shown before, our interviewees corroborated such ideas, pointing to their specific relationships with vertical entities (Ministry of Agriculture) and the challenges experienced from competition regulators including the CADE. This observation shows that companies are aware and respond differently to matters within the industrial policy level.

\section{Articulation with foreign governments and international organizations}

MNCs' access and entrance to new foreign markets often demands interaction between home and host country governments. The Brazilian MNCs interviewed find that it is quite hard to start a dialogue with foreign governments without the support of home country institutions. Moreover, as pointed out by previous research, MNC bargaining power decreases once FDI has been committed (Henisz \& Zelner, 2005). Thus, home country government support seems to also assist Brazilian MNCs' international strategies after they are established in a foreign country.

Evidence about the articulation between home and host country governments indicates the adoption of different and complementary mechanisms, mainly through Ministries and investment promotion agencies (even if they have a mixed capital ownership structure). One example presented in our field notes stresses the Brazilian government role in accessing the Japanese swine market. Brazilian exporters faced sanitary barriers that were often alleged to be technical barriers. To overcome them, companies looked for government diplomacy assistance. The Brazilian government 
organized bilateral trade missions, generally involving members of the Ministry of External Relations, Ministry of Development, Industry and Foreign Trade, and Ministry of Agriculture, aiming to negotiate with their counterparts, exchange information and conduct technical visits.

Besides opening markets abroad, home country governments can communicate with foreign governments and other host country's stakeholders in order to solve MNCs conflicts, similar to what has occurred with Odebrecht, in Ecuador, and Petrobras, in Bolivia, in 2008. Struggles with foreign stakeholders led to the creation of a new energy department inside the Brazilian Ministry of Foreign Affairs, capable of dealing with the specificity of these episodes (Freitas, 2011).

\section{Synthesis of government influence mechanisms}

According to our research, home country governments adopt a series of mechanisms to encourage flows and maintenance of outward FDI, either by conceding direct benefits to MNCs in comparison to other firms or by reducing barriers created by other actors. It is important to notice that not all forms of influence are converted into MNCs' benefits, as governments have to respond to demands from different actors in society with divergent interests.

Governments have formal and informal mechanisms to influence MNCs. Formal mechanisms are those expressed in norms and rules, codified public policies, public structures and support apparatus. Examples of formal mechanisms include regulations about limits on ownership, control and cross-border transfers of production factors by an MNE, or competitive policies released by federal government, which draws actions involving several governmental entities with the purpose of stimulating a greater engagement of companies into internationalization.

However, formal mechanisms are often weak and can be replaced by more fluid and individualistic interactions (Schneider \& Soskice, 2009). This is consistent with the evidence found concerning the Brazilian environment. Informal mechanisms are based on personal networks and rooted in socially accepted behavioral patterns, such as paternalism and corruption. They are often used by governments to reach specific goals, for instance to select strategic sectors and actors on the domestic market in order to create "national champions".

In addition, evidence collected suggests that a significant part of foreign trade and investment issues are treated at the federal government level. We have identified entities that supply direct channels of dialogue with MNCs, such as commerce related ministries, the development public bank BNDES, and traditional legislative instances. Autonomous agencies, like the Brazilian Trade and Investment Promotion Agency (Apex-Brasil), BNDESPAR (BNDES' commercial branch), stateowned companies and pension funds are indirect channels that intermediate government dialogue with Brazilian MNCs.

Table 4 classifies the ways governments influence national MNCs according to types of mechanisms (formal and informal) and channels of action used by governments to operationalize their influence. 
Table 4

Mechanisms of Government's Influence on National MNCs and Channels of Actions

\begin{tabular}{lll}
\hline & & \multicolumn{2}{c}{ Action } \\
& Direct & Indirect \\
\hline & $\begin{array}{l}\text { Traditional mechanisms of governmental } \\
\text { influence through the Executive, Legislative } \\
\text { and Judiciary branches. }\end{array}$ & $\begin{array}{l}\text { Mechanisms created by governments that } \\
\text { allow better adaptation for formal dialogue } \\
\text { with the private sector. }\end{array}$ \\
& $\begin{array}{l}\text { Example. Articulation with foreign } \\
\text { governments; supply of resources for } \\
\text { internationalization. }\end{array}$ & $\begin{array}{l}\text { Example: articulation with foreign } \\
\text { governments and government shareholder } \\
\text { participation. }\end{array}$ \\
\hline \multirow{2}{*}{ Informal } & $\begin{array}{l}\text { Invisible mechanisms mediated by personal } \\
\text { networks and informal institutions that }\end{array}$ & $\begin{array}{l}\text { Invisible mechanisms, implemented through } \\
\text { personal networks with local and foreign } \\
\text { penetrate the public sphere. }\end{array}$ \\
& $\begin{array}{l}\text { Ex.: selection of national champions and } \\
\text { corruption. }\end{array}$ & $\begin{array}{l}\text { Ex.: articulation with foreign governments } \\
\text { based on personal contacts }\end{array}$ \\
\hline
\end{tabular}

Note. Source: Elaborated by authors.

\section{Political strategies}

Public policies and the political decision-making process, whether at the district, state or federal level, affect the relative costs involved in a company's international expansion. Thus, the political environment is a key component for MNCs' strategies. As described below, we identified five political strategies that Brazilian MNCs use in order to access governmental bodies and represent their interests in the public sphere.

\section{Financial donations to political parties}

In Brazil, financial donations are a political strategy that directly links DCMC's to individual politicians or political parties. While candidates and political parties need funds to strengthen their campaigns and increase their chances for election, companies seek to support candidates with a high probability of election in order to have their industries well-represented in the public agenda.

Deciding who to support and transfer resources to their campaigns is a strategic decision for MNCs and can define how government relations will be managed in the years after the election. Evidence suggests that Brazilian MNCs invest in candidates according to their sectorial agenda rather than their left-right spectrum. For example, a respondent from Firm 2 stated that "to support the elections, we don't look at the party, we look at people linked to the agribusiness sector who advocate for the sector, if we have a candidate more sensitive to the agribusiness cause, we will support him or her" (Firm 2, field note). When supported candidates are elected, companies' ability to influence thematic public policies in the next mandate increases. It may also help companies to make their interests represented in the broader industrial policy agenda, which may be reflected in better official loans conditions, such as those from BNDES.

Most of Brazilian MNCs operating in the animal protein-processing sector have made legal political donations. According to data from the Brazilian Superior Electoral Court (TSE), JBS has donated over US\$6 million to candidates and political parties from 2006 to 2010, and has been one of the largest donors to the Workers Party (PT), the current ruling party (Transparência Brasil, 2010). In 2006, 18 supported deputies were elected, the majority from the mid-west region. In 2010, 39 parliamentarians were supported from 15 states. 
Table 5 shows evidence that suggests that Brazilian companies with higher levels of internationalization are amongst the major donors during Brazilian elections. From the top 10 companies that have donated more money to the winning presidential candidate in 2010 elections, 7 were Brazilian MNCs and 5 of them were listed among the ranking of Valor Multinacionais Brasileiras (2011), accounting for $28.72 \%$ of total donations. Their industries also benefited from federal government programs such as the Growth Acceleration Program (Programa de Aceleração do Crescimento $[\mathrm{PAC}])$. Inside the PAC, the Family Allowance program increased food intake and sugar consumption, and the program My Home, My Life boosted the market for real estate developers.

Table 5

Companies’ Donations for Winning Candidate Campaign, Presidential Elections 2010

\begin{tabular}{rllccc}
\hline Rank & Donator & Industry & $\begin{array}{c}\text { Internationalization } \\
\text { Ranking 2011 }\end{array}$ & Total & Weight \\
\hline 1 & JBS S/A & foodstuffs & 1 & $\mathrm{R} \$ 8,049,120.13$ & $7.19 \%$ \\
2 & Camargo Corrêa & conglomarate & 18 & $\mathrm{R} \$ 7,601,946.79$ & $6.79 \%$ \\
3 & Andrade Gutierrez & construction and engineering & 6 & $\mathrm{R} \$ 4,561,168.07$ & $4.07 \%$ \\
4 & Itau Unibanco & finance & 35 & $\mathrm{R} \$ 4,000,000.00$ & $3.57 \%$ \\
6 & Cosan & sugar and ethanol & - & $\mathrm{R} \$ 3,264,365.38$ & $2.91 \%$ \\
7 & Construtora OAS & construction and engineering & 23 & $\mathrm{R} \$ 2,683,040.04$ & $2.40 \%$ \\
9 & ARG & construction and engineering & - & $\mathrm{R} \$ 2,000,000.00$ & $1.79 \%$ \\
\hline & & & $\mathrm{R} \$ 32,159,640.41$ & $28.72 \%$ \\
\hline
\end{tabular}

Note. Source: Elaborated by authors based on Transparência Brasil. (2008, outubro). Quem financia quem nas eleições. Doadores a candidatos [Ás Claras]. Retrieved from http://www.asclaras.org.br/@index.php?ano=2008; Transparência Brasil. (2010, outubro). Quem financia quem nas eleições. Doadores a candidatos [Ás Claras]. Retrieved from http://www.asclaras.org.br/@index.php?ano=2010; O Estado de São Paulo. (2010b, dezembro 1). Veja o ranking das 220 empresas que mais doaram para a campanha de Dilma. Política. Retrieved from http://blogs.estadao.com.br/voxpublica/2010/12/01/veja-o-ranking-das-220-empresas-que-mais-contribuiram-para-a-campanha-de-dilma; Toledo, J. R. (2010). Veja o ranking das 220 empresas que mais doaram para a campanha de Dilma [Web log post]. Retrieved from http://blogs.estadao.com.br/vox-publica/2010/12/01/veja-o-ranking-das-220-empresas-que-mais-contribuiram-para-acampanha-de-dilma

Donations can also occur after the election. For example, the President of the National Finance Committee of the Workers Party received donations from 46 companies for amounts greater than US\$6 million after the campaign. According to the newspaper O Estado de São Paulo (2010a) the sugarcane industry made the biggest donation to help close the debits of Dilma Rousseff's campaign after the election. Cosan, the largest in the industry, made a donation of US\$3.5 million, while the Amaggi Group contributed with US\$1 million. The Brazilian sugarcane and alcohol industry is closely monitoring government negotiations to increase access to US market.

\section{Personal connections}

Brazilian business-government history of entanglement had its first milestone in 1930, when entrepreneurs eventually incorporated into the coalition to support President Getulio Vargas. This pact was quintessential to lead to the transition from agro-export economy to the urban-industrial society (Diniz, 2010). Since then industrial entrepreneurs and public bureaucracy have been central actors in Brazilian political pacts (Bresser-Pereira, 2009).

Personal connections in Brazil are powerful mechanisms to influence government decision makers. Although economic development and democracy reforms have made the interaction process more transparent, there is still huge influence from paternalism, nepotism, patronage and other informal mechanisms. For example, in the agriculture sector, Brazilian MNCs, such as producers of 
fruit juice and alcohol/ sugar cane, historically have close relationships that facilitate access to authorities. This is an individual informal strategy that is difficult to copy and with potentially high returns.

\section{Personal service}

DCMC's can establish links to governments when a firm representative serves in a political capacity. In Brazil, that was a usual strategy during President Lula's administration (2002 to 2010). Examples include vice president José Alencar, shareholder of Coteminas, one of the largest textile groups in the country, Roberto Rodrigues, previous president of ABAG (the Brazilian Agribusiness Association), as Minister of Agriculture, and Luiz Fernando Furlan, chairman of the board of Sadia, now BR Foods, a large Brazilian group manufacturer and exporter of food, who was indicated for the Ministry of Development, Industry and Foreign Trade. An iconic case in Brazil is Jorge Gerdau, founding of Gerdau group, one of the largest business groups in the Brazilian steel industry, which operates in over 14 countries and has revenues of more than US\$15 billion. Since May of 2011, Gerdau is the chairman of the Brazilian Chamber of Management Policy, Performance and Competitiveness, which is responsible for advising government on policies to improve competitiveness. Over 200 entrepreneurs and executives sponsor the project, including Carlos Alberto Sicupira, a partner at AB Inbev, Pedro Passos, partner and director of Natura, and David Feffer, chairman of Suzano Holding (Valor Multinacionais Brasileiras, 2011).

Businessman may also serve in a political capacity by affiliating with political parties and running for elections. For example, Jose Batista Junior, the founder of JBS, has joined the PSB (Social Party of Brazil) to increase JBS political participation in the State of Goiás and facilitate a future application for governor. Goiás is JBS's home state.

\section{Boards composed of ex-politicians and former officials from state enterprises}

Hillman (2005) asserts that one way to link a firm with the government is by appointing expoliticians to the board of directors. Analyzing the composition of board of directors from large Brazilian DCMC's in sectors such as agribusiness, construction and pulp and paper, we found the names of career employees from BNDES, ministers and officials with experience in pension funds and public companies. Usually, they are invited to join the board as independent advisors and get involved with the company's strategy. Our interviewees asserted that board members linked to the government are considered very influential because of their know-how in dealing with public sectors. This political strategy can also be used to complement and reinforce other strategies, since former officials have a better understanding of public procedures and have developed personal connections with current officials.

\section{Industry associations}

One of the main roles of an industry association is to represent and defend industry demands within the government with greater bargaining power, since it accounts for a high level of employability and a large slice of the country's income. Associations get involved in activities like discussing changes in legislations, requesting support related to foreign markets access, advocating for preferential tax rates, double taxation agreements, price controls, customs control and procedures related to foreign trade. Moreover, they can also act as arbitrators, mediating differences and creating convergence within the industry, so that the industry position is cohesive before drawing the attention of authorities responsible for public policy processes.

Companies can resort to associations as a collective political strategy. They are less expensive and risky than individual political strategies, however benefits awarded may be distributed to all members or even free riders. In order to obtain superior returns, firms can combine their political strategies with market strategies. For example, firm 2 has resorted to an association as a way to speak 
with the home country government and ask it to facilitate access to the Japanese market. At the same time it started a dialogue with potential suppliers and distributors in Japan to secure exclusivity and create entrance barriers against other Brazilian competitors.

Associations are a place to monitor competitors and to meet goals through joint action. Choosing the meat sector as a priority in the Policy for Productive Development, towards its consolidation and its internationalization, indicates the strength of this industry association and the benefits it may bring to its associates. After all, even if entrepreneurs have direct access to the authorities through personal connections, many situations can only be heard and discussed when articulated by industry representatives. A good example is the work conducted by the Brazilian Union of Sugar Cane Industry (UNICA) that has signed a provisional measure in December 2011 to stimulate ethanol storage domestically and avoid price fluctuation in harvests of sugar cane. The text of this provisional measure provides producers with federal funding at lower interest rates than the market so that they can build buffer stocks.

\section{Conclusion}

This study works towards a better recognition of the political aspects in DMNCs' entry and expansion phases in international markets. We focus on the understanding of the mechanisms governments use to foster the internationalization process of national firms and how DMNCs have overcome barriers to compete internationally by nurturing strong ties with home country governments. Internationalization affects the opportunities and constraints facing social and economic actors, and therefore their policy preferences (Milner \& Keohane, 1996). We considered firms and governments as bounded rational actors that engage in political dialogue to pursue rent-seeking or businessman selfinterests, on one side, and development goals or politicians' and bureaucrats' self-interests, on the other.

Since the 1990s, an exogenous easing of international exchange have induced reforms in Brazil towards a political economy in which private enterprise, including foreign investment, assumes expanded responsibility for economic development (Onis, 2000). We analyzed the Brazilian government's role in promoting and securing OFDI during DCMCs' first time as global players, a role that can be compared to American, European and Japanese governments during the first and second wave of internationalization. The policy mechanisms that enhance domestic firms' international insertion are not exclusive to developed or developing countries, but they can be better investigated considering country specific variable, taking into account both demand (actors' preferences, weighted by their market power and their propensity for collective action) and supply side (political institutions, politicians' interests and prevailing ideas in a society) for public policies. Future research can also engage in comparative analysis between home country government mechanisms from developed and developing countries today. In fact, the US government has played a continuous role in large MNCs' recoveries during the financial crisis.

Our goal in this work was to pay attention to the combination of mechanisms from both Brazilian domestic and foreign policy that influence Brazilian DMNCs internationalization. Although this study shows evidence that could easily relate to other emerging economies, any potential generalization should take into account the specific trajectory that has led Brazil to its actual state. For instance, the large presence of natural resources, its recent military regime, and its longer industrialization experience (when compared to its Asian counterparts) may suggest that there are specific mechanisms that are unique to the nation (Etzkowitz \& Brisolla, 1999). However, key similarities in industrial, trade and commercial policies including interventionism, protectionism and the selection of niche growth areas (such as chaebols or national champions) suggests that governments in emerging economies play a unique role in shaping the international faith of its national competitors (Rasiah et al., 2010). 
Political institutions reflect domestic actor's policy preferences, since they are intentionally created to guarantee the pursuit of particular policies (Milner \& Keohane, 1996). The convergence of preferences between Brazilian political and economic actors towards an increase in their international insertion has led to public policies that aim to benefit Brazilian MNCs and to corporate political activity that aims to extract above-average returns from them. The case shows the relevance of context-specific analysis in understanding MNC strategies based on an environment that differs from most CPA literature, which has focused on two-party systems, checks and balances and regulated lobbying. Instead, Brazil is a multi-party system with the prevalence of policy networks, defined as systems of informal relationships between rational individuals that create a stable infrastructure for the exchange of personal favors (Verdier, 1995).

Our findings suggest that although Brazilian companies' decisions to internationalize are mainly influenced by factors in the market environment, the home country political environment is a key element of DMNCs' strategies to access resources that drive FDI and the internationalization path of companies. Home country governments can support companies both in entry phases and after they have been established in foreign markets. Brazilian national champions exemplify the type of DMNCs that have pursued political and market strategies that enable them to catch-up with established internationals players and have access to significant incentives from the Brazilian government, such as subsided capital, facilitated dialogue with foreign governments and favorable competition policies.

We argue that there is an association between MNCs' political activity and the access to higher political benefits in the home-country political environment. Firms may perceive high returns potential in engaging in the policymaking process, especially in priority issues for the government, such as its global economic presence. We suggest that further research should incorporate evidence from other develop and developing firms in order to address two additional questions; determine the extent to which the choice, application and results from political strategies are different between developed and developing firms; to question the historical, social and cultural traits that affect the availability of political connections and the extent to which formal or informal ones are implemented. We would expect future studies to incorporate quantitative information as well as to use appropriate designs in order to isolate the causality direction of political activity.

\section{References}

Associação Brasileira das Indústrias Exportadoras de Carnes. (2012, fevereiro 29). [Entrevista com o Antônio Camardelli]. Presidente da ABIEC. Retrieved from http://www.abiec.com.br/noticia.asp?id=779\#.Uj8VnWt5mSM

Blumentritt, T. P. (2003). Foreign subsidiaries' government affairs activities. Business \& Society, 42(2), 202-233. doi: 10.1177/0007650303042002003

Blumentritt, T. P., \& Nigh, D. (2002). The integration of subsidiary political activities in multinational corporations. Journal of International Business Studies, 33(1), 57-77. doi: 10.1057/palgrave.jibs.8491005

Boddewyn, J. J. (1988). Political aspects of MNE theory. Journal of International Business Studies, 19(3), 341-363. doi:10.1057/palgrave.jibs.8490392

Boddewyn, J. J., \& Brewer, T. L. (1994). International-business political behavior: New theoretical directions. Academy of Management Review, 19(1), 119-143.

Bresser-Pereira, L. C. (2009). From the national-bourgeois to the associated dependency interpretation of Latin-America. [Texto para discussão, $\mathrm{N}^{\circ}$ 185]. São Paulo: Escola de 
Economia de São Paulo da Fundação Getulio Vargas. Retrieved from http://www.bresserpereira.org.br/papers/2009/09.11.From_the_national-bourgeois.TD-185.pdf

Caves, R. E. (1996). Multinational enterprise and economic analysis. Cambridge: Cambridge University Press.

Diniz, E. (2010). Empresariado industrial, representação de interesses e ação política: trajetória histórica e novas configurações. Política e Sociedade, 9(17), 101-121. Retrieved from http://www.journal.ufsc.br/index.php/politica/article/viewArticle/15675. doi: 10.5007/21757984.2010v9n17p101

Drago, B., \& Nogueira, M. (2013). Brazil: abuse of dominance. The antitrust review of the Americas 2013. Global Competition Review. Retrieved from http://globalcompetitionreview.com/reviews/46/sections/158/chapters/1808/

Dunning, J. H. (1988). The eclectic paradigm of international production: a restatement and some possible extensions. Journal of International Business Studies, 19(1), 1-31. doi: $10.1057 /$ palgrave.jibs. 8490372

Etzkowitz, H., \& Brisolla, S. N. (1999). Failure and success: the fate of industrial policy in Latin America and South East Asia. Research Policy, 28(4), 337-350. doi: 10.1016/S00487333(98)00077-8

Fleury, A., \& Fleury, M. T. L. (2009). Understanding the strategies of late-movers in international manufacturing. International Journal of Production Economics, 122(1), 340-350.

Fleury, A., \& Fleury, M. T. L. (2011). Brazilian multinationals: competences for internationalization. Cambridge: Cambridge University Press.

Freitas, T. (2011). BNDES paga $28 \%$ mais por ação da JBS e põe fim a debêntures. Folha de São Paulo. Retrieved from http://www1.folha.uol.com.br/fsp/mercado/me1905201121.htm

Gammeltoft, P., Pradhan, J. P., \& Goldstein, A. (2010). Emerging multinationals: home and host country determinants and outcomes. International Journal of Emerging Markets, 5(3/4), 254265. doi: $10.1108 / 17468801011058370$

Garret, G., \& Lange, P. (1995). Internationalization, institutions and political change. International Organization, 49(4), 627-655. doi: 10.1017/S0020818300028460

Goldstein, A., Bonaglia, F., \& Mathews, J. (2006). Accelerated internationalization by emerging multinationals: the case of white goods. Retrieved from http://www.oecd.org/dev/36317032.pdf

Hay, C. (1999). The political economy of new labour: labouring under false pretences?. Manchester: Manchester University Press.

Henisz, W. J. (2000). The institutional environment for multinational investment. Journal of Law, Economics, and Organization, 16(2), 334-364. doi: 10.1093/jleo/16.2.334

Henisz, W. J., \& Williamson, O. E. (1999). Comparative economic organization-within and between countries. Business and Politics, 1(3), 261-278. doi: 10.1515/bap.1999.1.3.261

Henisz, W. J., \& Zelner, B. A. (2005). Legitimacy, interest group pressures, and change in emergent institutions: the case of foreign investors and host country governments. The Academy of Management Review, 30(2), 361-382. doi: 10.5465/AMR.2005.16387892

Hillman, A. J. (2005). Politicians on the board of directors: do connections affect the bottom line? Journal of Management, 31(3), 464-481. doi: 10.1177/0149206304272187 
Hillman, A. J., \& Hitt, M. A. (1999). Corporate political strategy formulation: a model of approach, participation, and strategy decisions. Academy of Management Review, 24(4), 825-842. doi: 10.5465/AMR.1999.2553256

Holburn, G. L. F., \& Zelner, B. A. (2010). Political capabilities, policy risk, and international investment strategy: evidence from the global electric power generation industry. Strategic Management Journal, 31(12), 1290-1315. doi: 10.1002/smj.860

JBS. (n.d.). Diretoria executiva e conselho fiscal. Retrieved from http://jbss.infoinvest.com.br/static/ptb/diretoria-executiva-e-conselho-fiscal.asp

Lall, S. (1983). The third world multinationals: the spread of third world enterprises. Chichester: J. Wiley \& Sons.

Langley, A. (1999). Strategies for theorizing from process data. Academy of Management Review, 24(4), 691-710. doi: 10.2307/259349

Luo, Y. (2004). A coopetition perspective of MNC-host government relations. Journal of International Management, 10(4), 431-451. doi: 10.1016/j.intman.2004.08.004

Marcus, A., Kaufman, A., \& Beam D. (1987). The pursuit of corporate advantage and the quest for social legitimacy. New York: Business Strategy and Public Policy.

Milner, H., \& Keohane, R. (1996). Internationalization and domestic politics: an introduction. In R. Keohane \& H. Milner (Eds.), Internationalization and domestic politics (pp. 3-25). New York: Cambridge Univ. Press.

Murtha, T. P., \& Lenway, S. A. (1994). Country capabilities and the strategic state: how national political institutions affect multinational corporations' strategies. Strategic Management Journal, 15(S2), 113-129. doi: 10.1002/smj.4250151008

O Banco Nacional de Desenvolvimento. (n.d.). Consulta às operações do BNDES. Retrieved from http://www.bndes.gov.br/SiteBNDES/bndes/bndes_pt/Institucional/BNDES_Transparente/Cons ulta_as_operacoes_do_BNDES/

O Banco Nacional de Desenvolvimento. (2009b, dezembro 23). A BNDESPAR subscreverá até US\$ 2 bilhões de debêntures da JBS. Retrieved from http://www.bndes.gov.br/SiteBNDES/bndes/bndes_pt/Institucional/Sala_de_Imprensa/Noticias/ 2009/Industria/20091223_JBS.html

O Banco Nacional de Desenvolvimento. (2009a, setembro 16). Setor de proteína animal. Retrieved from

http://www.bndes.gov.br/SiteBNDES/bndes/bndes_pt/Institucional/Sala_de_Imprensa/Comunic ados/2009/meioambiente/20090916_setor_proteina_animal.html

O Banco Nacional de Desenvolvimento. (2011). BNDES Participações S.A. - BNDESPAR: Relatório da administração. Retrieved from http://www.bndes.gov.br/SiteBNDES/export/sites/default/bndes_pt/Galerias/Arquivos/empresa/ download/RelatAdmBPAR1211.pdf

O Estado de São Paulo. (2010a, agosto 3). Os riscos do Tesouro nos empréstimos ao BNDES. Economia \& Negócios. Retrieved from http://www.estadao.com.br/noticias/impresso,os-riscosdo-tesouro-nos-emprestimos-ao-bndes,589687,0.htm

O Estado de São Paulo. (2010b, dezembro 1). Veja o ranking das 220 empresas que mais doaram para a campanha de Dilma. Política. Retrieved from http://blogs.estadao.com.br/voxpublica/2010/12/01/veja-o-ranking-das-220-empresas-que-mais-contribuiram-para-a-campanhade-dilma/ 
Onis, J. de (2000). Brazil's new capitalism. Foreign Affairs, 79(3), 107-119.

Pearce, J. L. (2001). Organization and management in the embrace of government. Mahwah, NJ: Lawrence Erlbaum.

Ramamurti, R. (2012). What is really different about emerging market multinationals? Global Strategy Journal, 2(1), 41-47. doi: 10.1002/gsj.1025

Rasiah, R., Gammeltoft, P., \& Jiang, Y. (2010). Home government policies for outward FDI from emerging economies: lessons from Asia. International Journal of Emerging Markets, 5(3/4), 333-357. doi: 10.1108/17468801011058415

Ring, P. S., \& Van de Ven, A. H. (1992). Structuring cooperative relationships between organizations. Strategic Management Journal, 13(7), 483-498. doi: 10.1002/smj.4250130702

Sargent, J., \& Ghaddar, S. (2001). International success of business groups as an indicator of national competitiveness. Latin American Business Review, 2(3/4), 97-121. doi: 10.1300/J140v02n03_05

Schneider, B. R., \& Soskice, D. (2009). Inequality in developed countries and Latin America: coordinated, liberal and hierarchical systems. Economy and Society, 38(1), 17-52. doi:10.1080/03085140802560496

Shapiro, I. (1994). Pathologies of rational choice theory: a critique of applications in political science. New Haven: Yale University Press.

The Economist. (2010, August 5). Brazil's development bank: Nest egg or serpent's egg? the economist. Retrieved from http://www.economist.com/node/16748990

Toledo, J. R. (2010). Veja o ranking das 220 empresas que mais doaram para a campanha de Dilma [Web log post]. Retrieved from http://blogs.estadao.com.br/vox-publica/2010/12/01/veja-oranking-das-220-empresas-que-mais-contribuiram-para-a-campanha-de-dilma

Transparência Brasil. (2008, outubro). Quem financia quem nas eleições. Doadores a candidatos [Ás Claras]. Retrieved from http://www.asclaras.org.br/@index.php?ano=2008

Transparência Brasil. (2010, outubro). Quem financia quem nas eleições. Doadores a candidatos [Ás Claras]. Retrieved from http://www.asclaras.org.br/@index.php?ano=2010

United Nations Conference on Trade and Development. (2011). World investment report 2011. Nonequity modes of international production and development. Retrieved from http://www.unctaddocs.org/files/UNCTAD-WIR2011-Full-en.pdf

United Nations Conference on Trade and Development. (2012). World investment report 2012. Towards a new generation of investment policies. Retrieved from http://www.unctaddocs.org/files/UNCTAD-WIR2012-Full-en.pdf

Valor Multinacionais Brasileiras. (2011, setembro). Valor Econômico, Ano 4 (4). Retrieved from http://www.revistavalor.com.br/home.aspx?pub=3\&edicao=4

Verdier, D. (1995). The politics of public aid to private industry: the role of policy networks. Comparative Political Studies, 28(1), 3-42. doi: 10.1177/0010414095028001001

Witt, M. A., \& Lewin, A. Y. (2007). Outward foreign direct investment as escape response to home country institutional constraints. Journal of International Business Studies, 38(4), 579-594. doi: $10.1057 /$ palgrave.jibs. 8400285 
Wright, M., Filatotchev, I., Hoskisson, R. E., \& Peng, M. W. (2005). Strategic research in emerging economies: challenging the conventional wisdom. Journal of Management Studies, 42(1), 1-33. doi: 10.1111/j.1467-6486.2005.00487.x 


\section{ANNEX A}

\section{Evidences}

\begin{tabular}{|c|c|c|}
\hline Evidence & Source & Type \\
\hline $\begin{array}{l}\text { "The motivation for our } \\
\text { international expansion came, } \\
\text { amongst other factors, from our } \\
\text { industry, which is at a favorable } \\
\text { moment in the country" }\end{array}$ & $\begin{array}{l}\text { *Interview with the Director of the } \\
\text { company A (translation produced by } \\
\text { authors) }\end{array}$ & $\begin{array}{l}\text { Favorable Regulation and } \\
\text { Legislation }\end{array}$ \\
\hline $\begin{array}{l}\text { "As resources to help our } \\
\text { internationalization, JBS sought out } \\
\text { capital from an IPO as well as } \\
\text { Bandespar" }\end{array}$ & $\begin{array}{l}\text { *Interview with the Director of the } \\
\text { company A (translation produced by } \\
\text { authors) }\end{array}$ & Personal Connection \\
\hline $\begin{array}{l}\text { "In the case of BNDES the bank } \\
\text { was oriented to support acquisitions } \\
\text { abroad" }\end{array}$ & $\begin{array}{l}\text { *Interview with the Director of the } \\
\text { company A (translation produced by } \\
\text { authors) }\end{array}$ & $\begin{array}{l}\text { Supply of subsidized resources for } \\
\text { internationalization }\end{array}$ \\
\hline $\begin{array}{l}\text { "For our merger with Bertim \& } \\
\text { Pilgrim's Pride the combined } \\
\text { operation had a contribution from } \\
\text { BNDES of about US } \$ 2 \text { billion" }\end{array}$ & $\begin{array}{l}\text { *Interview with the Director of the } \\
\text { company A (translation produced by } \\
\text { authors) }\end{array}$ & $\begin{array}{l}\text { Personal Connections : Supply of } \\
\text { subsidized resources for } \\
\text { internationalization }\end{array}$ \\
\hline $\begin{array}{l}\text { "Without the contribution from } \\
\text { BNDES this transaction would have } \\
\text { not been possible, or would have } \\
\text { been slower" }\end{array}$ & $\begin{array}{l}\text { *Interview with the Director of the } \\
\text { company A (translation produced by } \\
\text { authors) }\end{array}$ & $\begin{array}{l}\text { Supply of subsidized resources for } \\
\text { internationalization }\end{array}$ \\
\hline
\end{tabular}

In terms of the Policy for Productive BNDES (2009a)

Industry Association

Development (PDP in Portuguese)

BNDES chose the meat sector as a

priority for the consolidation and

internationalization processes

\begin{tabular}{|c|c|c|}
\hline $\begin{array}{l}\text { BNDESPAR will provide } \\
\text { guarantees for a } 100 \% \text { of bonds } \\
\text { issued by JBS, exchangeable into } \\
\text { Brazilian Depositary Receipts of } \\
\text { JBS in the USA or alternatively } \\
\text { exchangeable into JBS shares in } \\
\text { case JBS USA decides not to open } \\
\text { its capital. This should occur by } \\
\text { December } 31,2010\end{array}$ & BNDES (2009b) & $\begin{array}{l}\text { Personal Connection: Supply of } \\
\text { subsidized resources for } \\
\text { internationalization }\end{array}$ \\
\hline $\begin{array}{l}\text { Given the fact that the IPO did not } \\
\text { go through, BNDES converts all } \\
\text { bonds for shares in JBS Brazil, with } \\
\text { its participation going from } 17 \% \text { to } \\
31 \%\end{array}$ & Freitas (2011) & $\begin{array}{l}\text { Personal Connection to } \\
\text { Government's shareholder } \\
\text { participation }\end{array}$ \\
\hline $\begin{array}{l}\text { JBS Board - Until August 2012: } \\
\text { Marcus Vinicius Pratini de Moraes } \\
\text { (Minister, founder of FUNCEX, }\end{array}$ & JBS (n. d.) & $\begin{array}{l}\text { Board composed of ex-politicians } \\
\text { and former officials from state } \\
\text { enterprises }\end{array}$ \\
\hline
\end{tabular}

member of the Advisory Board at

$\mathrm{BM} \& \mathrm{~F}$, president of ABIEC); Peter

Dvorsak (BNDES, BNDESPAR);

Umberto Conti (FUNCEF, Special

Advisor to the President) 
Membership in associations: ABRAFRIGO - associação brasileira de frigoríficos; ABIEC associação brasileira de industries exportadoras de carne (the President is the director of business strategy for JBS, Antônio Jorge Camardelli)

JBS was the largest single donor to Dilma's 2010 Presidential campaign

(INTERVIEWER) "The difference in the organizational structure of JBS in Brazil and the US responds to differences in the ways in which government relations are implemented in both countries?" (INTERVIEWEE) "Yes, although we know that everyone does lobbying in Brazil"
Associação Brasileira das Indústrias Industry Association / Personal Exportadoras de Carnes (2012) Connection

Transparência Brasil. (2008, 2010) Financial Donations to political parties

*Interview with the Director of the Personal Connection company A (translation produced by authors)

Note. *company A is a fictitious name. Company A was interviewed by the authors in August, 2011. 


\section{ANNEX B}

Outward FDI Projects by State-owned TNCs, by Home Region/Economy, 2003-2010

\begin{tabular}{lrrrrrrrr}
\hline & $\mathbf{2 0 0 3}$ & $\mathbf{2 0 0 4}$ & $\mathbf{2 0 0 5}$ & \multicolumn{1}{c}{$\mathbf{2 0 0 6}$} & \multicolumn{1}{c}{$\mathbf{2 0 0 7}$} & $\mathbf{2 0 0 8}$ & $\mathbf{2 0 0 9}$ & $\mathbf{2 0 1 0}$ \\
\hline Developed countries & 34414 & 48570 & 55342 & 55168 & 85881 & 98137 & 84937 & 56051 \\
Developing countries & 36895 & 43021 & 45535 & 101965 & 91100 & 111606 & 74254 & 85698 \\
China & 11462 & 5592 & 8193 & 16767 & 21267 & 32492 & 28613 & 38899 \\
Malaysia & 4930 & 1432 & 2572 & 2050 & 4288 & 4813 & 2854 & 19811 \\
Brazil & 5344 & 1085 & 2391 & 1740 & 2501 & 9592 & 2381 & 5808 \\
United Arab Emirates & 447 & 258 & 17520 & 45516 & 27108 & 28297 & 20470 & 5713 \\
Korea, Republic of & 904 & 1444 & 2055 & 86 & 1095 & 2800 & 4353 & 3734 \\
South Africa & 2135 & 15352 & 1174 & 446 & 1358 & 2166 & 2323 & 2225 \\
Singapore & 2196 & 4609 & 2689 & 6309 & 6574 & 2724 & 1191 & 1739 \\
Kuwait & 1023 & 1346 & 735 & 10071 & 4109 & 4501 & 286 & 1263 \\
Colombia & - & - & - & 536 & 340 & - & - & 1197 \\
Qatar & - & 264 & 236 & 53 & 5265 & 5331 & 4943 & 1063 \\
Venezuela & 2257 & 48 & 171 & 897 & 627 & 1501 & 374 & 780 \\
Bahrain & 5 & 2 & 2 & 415 & 162 & 422 & 28 & 745 \\
Angola & - & - & - & - & 24 & - & - & 493 \\
India & 2842 & 6002 & 3654 & 13905 & 1096 & 4529 & 5174 & 487 \\
Saudi Arabia & 146 & 5071 & 178 & 1733 & 12831 & 7309 & 58 & 473 \\
\hline
\end{tabular}

Note. The data include major SOE investors. FDI projects include both cross-border M\&As and greenfield FDI projects. Countries associated with indirect investments by third-parties have been removed. Source: United Nations Conference on Trade and Development. (2011). World investment report 2011. Non-equity modes of international production and development (pp. 2-16). Retrieved from http://www.unctad-docs.org/files/UNCTAD-WIR2011-Full-en.pdf; United Nations Conference on Trade and Development. (2012). World investment report 2012. Towards a new generation of investment policies (pp. 2-16). Retrieved from http://www.unctad-docs.org/files/UNCTAD-WIR2012-Full-en.pdf 